\title{
Exploration on the Reasons of College Students' Voluntary Unemployment and Selective Unemployment and Its Countermeasures
}

\author{
Wanyun Liu \\ College of Business Administration \\ Henan Institute of Education \\ Zhengzhou, Henan, China 450046
}

\begin{abstract}
It is an indisputable fact that it is difficult for college students to obtain employment, and the unemployment is inevitable. Traditional studies suggest that frictional unemployment and structural unemployment are the most common among college students. But in the last two years, there have been some new situations, such as voluntary unemployment and selective unemployment. It is the key point of this paper to explore the reasons, advantages and disadvantages, and countermeasures to these problems. Through research, the author is expected to give some constructive suggestions to these employment problems of college students.
\end{abstract}

Keywords-voluntary unemployment; selective unemployment; problems; countermeasures

\section{INTRODUCTION}

The data provided by the Ministry of Education show that the number of college graduates in the country respectively was 7490000 in 2015 and 7270000 in 2014 . The number of graduates has created a new record. And the employment of college students has become the focus of social concern and academic research. The unemployment of college students is inevitable. According to the research of Ceng Xiangquan of Renmin University of China, the most common are frictional unemployment and structural unemployment among college students [1]. "2014 Chinese College Students Employment Report" shows that there are 570000 unemployed college students among college graduates in 2013. Among them, more than 100000 college students have the ability to work, but they give up the employment opportunity and select unemployment [2]. In other words, in recent years there have been new situations among college students, such as voluntary unemployment and selective unemployment. It is because of proud and arrogant attitude of college students or the reality of the society? The author is expected to give some suggestions in the solution of the employment problems of college students.

\section{THE STATUS OF VOLUNTARY UNEMPLOYMENT AND SELECTIVE UNEMPLOYMENT OF COLLEGE STUDENTS}

The voluntary unemployment is an economic concept proposed by the British Bourgeois Vulgar Economist Arthur Pigou Cecil. It refers to the unemployment of someone who has work ability, voluntarily gives up job opportunities and is not willing to find jobs. The selective unemployment refers to the unemployment of someone who has work ability, but gives up one or some employment opportunities in the process of choosing a job and is unemployed in a certain period of time.

The author has carried out investigation on unemployed college students for a month, and found that the status of voluntary unemployment and selective unemployment of college students is as follows:

\section{A. Turn Their Nose up at General Work and Prefer Unemployment.}

Zhang Yang (pseudonym) has graduated from a university in Beijing for two full years. In his opinion, these two years he has not been idle. He is waiting and looking for opportunities, until he could find a good job with formal career preparation, a monthly salary of more than 5000 yuan and providing him Beijing Household. He takes a complete dislike to the job with a monthly salary lower than three thousand yuan. Lately, there was an online video about a postgraduate who return back home to farm. Her father was angry, and took poison. And this postgraduate became a "hot person". She is native to Hebei Baoding and surnamed Miao. She was ever the pride of the whole village because of her success in academy. But now she gave up job and return back to farm because of low pay. Her father couldn't suffer this pressure and committed suicide by taking poison. This father selected an extreme way. However, that college students and postgraduates turn their nose up at general work is very common around us. 


\section{B. A Number of College Students would like to "Study Abroad", or Become a "Civil Official", so They are not Eager to Find a Job after Graduation.}

In order to realize their desires, they prefer to choose to be unemployed temporarily. This year has been the third time for Wang Ran (pseudonym) to apply for postgraduate in the Economic Management Institute of Tsinghua University. The persistence of Wang Ran is because that he has his investment and production calculation. He thinks ordinary undergraduate could maintain food and clothing according to the city's living standards even if they go to work after graduation. If he could be admitted by a famous postgraduate school, his platform will be improved after graduation and he can go further in his future career. A lot of college students focus on taking the civil service examinations, so there is a spectacular craze for civil service examinations. On October 22,2015 , the civil service exam registration has not ended, and the competition ratio of a job in Chongqing Investigation Crops was 6348 to 1 made by the National Bureau of Statistics, which refreshed the record of the most intense competition in state test registration in recent years in one fell swoop. In the first time Harbin openly recruited personnel for the environmental sanitation system with staffing of government affiliated institutions in the whole society, 457 posts had attracted 11539 applicants, including nearly 30 graduate students [3].

\section{Select Unemployment and Wait for the Arrangement of Job from the Family Members.}

Chinese parents arrange kindergarten, and select primary, middle and high schools for their children. They help their children select colleges and specialty, and arrange job for their children when they are graduated. For today's college students, it has become accustomed to rely on parents upon every thing. If the parents do not find a suitable job for them, the students have to choose the unemployment. According to a survey of Henan Institute of Education in 2014, $40 \%$ of students are waiting for their parents to arrange a job for them.

\section{ThE REASON ANALYSIS OF COLLEGE STUDENTS VOLUNTARY UNEMPLOYMENT AND SELECTIVE UNEMPLOYMENT}

\section{A. Be Influenced by the Traditional Concept and Have a Relative High Expectation on Employment.}

Knowledge changes destiny. College students have a good plan and vision for their future, and many parents also hope that their children can find a better job. Especially for college students from the rural areas, they treat receiving higher education as an opportunity to change their fate. They have an expectation in their work environment, wages, welfare, and development prospects. According to the survey of Tsinghua University, $65 \%$ of college students expect their salary over 3000 yuan; $31 \%$ of college students expect their salary over 5000 yuan. In the choice of employment, $70 \%$ of college students hope to stay in Beijing, directly-controlled municipalities or coastal cities. In the expectation of employment posts, $60 \%$ of the graduates hope to stay in the state organs or institutions [4]. The Research Report of "2013 Session of University Graduates in the Workplace" jointly promulgated by the people's daily and Mycos on December 11, 2013 shows that $30.1 \%$ of college students first choose jobs with "high social status". Secondly they choose jobs with "high income" $(24.6 \%)$. Thirdly they choose jobs that can "obtain new knowledge frequently" $(21.6 \%)$. The following includes a wide range of communication $(14.1 \%)$, more freedom time $(8.2 \%)$, and etc. When there is a gap between the reality and the ideal, they would rather choose unemployment. Thus, there appear "oncampus drifting group" and "NEETs", and a large number of "voluntary unemployment" and "selective unemployment".

\section{B. The Urban \& Rural Dualistic System Divides the Labor Market.}

Because of the unbalanced development of urban and rural areas in China, there is a big difference among students in their work environment, wages and welfare benefits. As a result, many college students would rather choose to be unemployed in urban markets, search and wait for employment opportunities. According to the questionnaire survey of college graduates from Peking University in 2014, the employment distribution of college graduates in 2014 is still in a trend of "going to the east and upward". The employed graduates accounted for $52.5 \%$ in the eastern region, $17.3 \%$ in the Central Region and $30.1 \%$ in the western region. According to employment sites, the employment graduate accounted for $51 \%$ in provincial capital or directly-controlled municipalities, $29.2 \%$ in prefecture-level city, $15.5 \%$ in county-level cities or counties, $3.8 \%$ in towns and $0.5 \%$ in countryside [5].

The study shows that there is a positive correlation between the unemployment rate of graduates and the probability of obtaining employment in the primary labor market, and the more likely the graduates may enter the labor market, the higher the unemployment rate is.

\section{Be Influenced by the Social Reality.}

The current college students hope to enter into an "insystem" unit, so they exert themselves to the utmost after graduation. Why college students are so obsessed with "insystem" unit? According to new reports from the "China Economic Weekly", the staff of "in-system" units could buy a suit of house in downtown at 1/8 of market price. In some "in-system" units, their staff could get an iPad6 in the annual lottery meeting in the worst case; some could have a big lunch with only one yuan. The enviable hidden benefits within the in-system units have a profound impact on employment direction of college students. The social reality has changed the values of college students. Some college students have determined to enter into "in-system" units since they were admitted by the school. If they couldn't get recruitment after graduation, they would rather to be unemployed. If excellent students are competing to enter the "in-system" units, it may mean that it has a world of difference between "in-system" units and "out-of-system" units. In other words, there are social equity issues. 
On the whole, the selective unemployment of college graduates is not good for our country. For the employment of college students, the main drawbacks of selective unemployment are as follows: it means that college graduates suffer setbacks in the initial period from school to society, which may have a negative impact on individual's psychology and growth path. College students persevere in their studies in spite of hardships for a decade years. They have their wish frustrated for they invest a lot but get no return. They have grown up but cannot earn their own living. In the aspect of a country, the selective unemployment of some college students and the absence of post of some units and the in-post of low-quality staff have resulted in waste of talent, not conducive to optimizing the allocation of human resource in the society, and improving the economic benefits of enterprises and society.

\section{SUGGESTIONS AND COUNTERMEASURES}

\section{A. Establish a Correct Concept of Employment.}

Schools, parents, and society together guide students to establish a correct outlook on life, values and career concept. With the popularization of the university education, the talents trained by university has transformed from the elite to the ordinary workers. College graduates should be able to recognize themselves, understand the professional, and understand the society correctly, and consider the importance of the goal and the possibility of achieving the goal, and try to find the meeting point of social interests and personal interests. They can go to the most needed areas of the country, and the places that can play their intelligence and wisdom, so that they can integrate into social practice as soon as possible. The biggest disadvantage of college students is the lack of experience. The graduates have been waiting for better opportunities, so they empty their job searching period. This is undoubtedly a passive thought. The longer the blanking period of graduates is, the more disadvantaged their future will be. It is not realistic to wait for a good opportunity for a long time, because the employers will particularly mind the attitude of job seekers. No units are willing to accept job seekers who are arrogant, and always escaping from reality.

\section{B. Further Strengthen Ideological Education and Policy Advocacy.}

Colleges and universities should treat ideological education as pioneering work to promote employment and entrepreneurship. Actively they should organize graduates to study and understand important speech of General Secretary $\mathrm{Xi}$ Jinping and the spirit of answering the letter of a graduate, exert themselves to cultivate students and help students practice the socialist core values, and guide the graduates to integrate personal dream into the great practice of the Chinese dream, so that graduates accomplish their goals in needed places. Colleges and universities can combine the characteristics of the young students, organize and guide graduates to practice in urban and rural grass roots and first production line, so as to help them understand national conditions, boot on the ground, change concepts and increase talent. They can help graduates adjust their employment expectations, plan professional career and actively obtain employment and start a business through excellent alumnus lecture, inviting experts and scholars explaining situations and entrepreneurs telling experience.

\section{The Government should Further Optimize the Fair Employment and Entrepreneurship Environment for College Graduates, and Realize Equal Opportunity for all at the Utmost.}

The government should establish the employment mechanism and supporting talent selection and supervision mechanism for college students, meanwhile constantly promote the reform of related personnel, labor employment, household management, and social security system. In addition, the government should strengthen the efforts to reform the income distribution system, solve the large income gap among different industries, and solve the invisible high income problems in "in-system" units. The committee member of National Education Advisory Committee and professor of Beijing Normal University Wang Shanmai said: "the college students who learn agriculture, medicine or teacher seldom go to countryside. It is not because these areas do not need them. It is because that we lack relevant encouragement mechanism. From one aspect, the treatment and encouragement for civil servants in eastern region are too excessive" [6]. It can correct the value of the young to solve the society equality problem. It not only helps students play their talent in the posts but also remedy the social morality.

\section{Greatly Guide College Graduates to the Grass Roots for Employment.}

It is suggested to further improve the service security mechanism to encourage graduates to the grass roots for employment, and perfect the tuition compensation and student loan compensation, follow-up studies and employment services policies. The government should continue to organize the grassroots service projects, such as "rural teacher of special post plan", "western plan", "collegegraduate village official", and "three supports and one assistance". The government can care for the work, growth and development of graduates through regular visits, comeafter training and other methods, further create conditions to guide the graduates to the grassroots areas, the central and western regions, and remote areas, and small and micro enterprises for employment. The relevant government departments should do a good job in realization of social security subsidies, training subsidies, tax relief, graduates settlement, personnel file management, and other policies in order to attract graduate for employment, and support more graduates to the grass roots to make contributions.

At same time, open green channel for college students to join the army, and further improve and implement the tuition compensation, loan compensation and tuition waiver, school reentry after retirement, employment and entrepreneurship and other policies to encourage more college students join the army and serve the country. 
E. Colleges and Universities should Pay More Attention to the Employment Quality of Graduates rather than the Quantity of the Graduates' Employment, and Better Adapt to the Development Needs of the Economy and Society.

According to the data of the survey report in New Observation on Campus Recruitment, more than $80 \%$ of the graduates have the experience of giving up interviews or employment. It means graduates have a lot of expectations and requirements on their first job. "Selective unemployment" is the performance of college students concerning the quality of employment. The large and all inclusive employment rate has been unable to win the people's attention. The concern on employment quality will no doubt become a new topic in the employment of college students in the future. Colleges and universities should take employment as orientation, constantly adjust discipline and specialty structure and optimize the structure of personnel training according to the requirements of wide direction, solid foundation, and flexible major orientation, and strive to develop more and better college graduates with innovative spirit and practical ability.

\section{REFERENCES}

[1] Zeng Xiangquan. Employment Environment in the Reform and the Employment of College Students in China. Beijing: Renmin University of China Press, 2004

[2] Qiu Chenhui. 2014College Students Employment Report, China Youth Daily, 2015 - 10 - 20

[3] Wu Hongpo. Unifying Labor Market and Easing Employment Pressure of College Students. China's National Conditions and Power. 2012 (10).

[4] Zhang Xueliang. Thinking about Hot TV Job-searching Program in the Difficult Employment Background of College Students. Chinese College Students, 2012 (18)

[5] Lai Desheng. 2014 Labor Market Report. Beijing: Beijing Normal University Press, 2014. 